IZA DP No. 2808

\title{
Productivity and Trade Orientation in
} UK Manufacturing

Marian Rizov

Patrick Paul Walsh

May 2007 


\title{
Productivity and Trade Orientation in UK Manufacturing
}

\author{
Marian Rizov \\ Middlesex University Business School \\ and Trinity College Dublin \\ Patrick Paul Walsh \\ Trinity College Dublin \\ and IZA
}

Discussion Paper No. 2808

May 2007

IZA
P.O. Box 7240
53072 Bonn
Germany

Phone: +49-228-3894-0

Fax: +49-228-3894-180

E-mail: iza@iza.org

\begin{abstract}
Any opinions expressed here are those of the author(s) and not those of the institute. Research disseminated by IZA may include views on policy, but the institute itself takes no institutional policy positions.

The Institute for the Study of Labor (IZA) in Bonn is a local and virtual international research center and a place of communication between science, politics and business. IZA is an independent nonprofit company supported by Deutsche Post World Net. The center is associated with the University of Bonn and offers a stimulating research environment through its research networks, research support, and visitors and doctoral programs. IZA engages in (i) original and internationally competitive research in all fields of labor economics, (ii) development of policy concepts, and (iii) dissemination of research results and concepts to the interested public.
\end{abstract}

IZA Discussion Papers often represent preliminary work and are circulated to encourage discussion. Citation of such a paper should account for its provisional character. A revised version may be available directly from the author. 


\section{ABSTRACT \\ Productivity and Trade Orientation in UK Manufacturing*}

Within a structural model we explicitly allow for the trade orientation of companies to estimate productivity dynamics within 4-digit UK manufacturing industries. We use the FAME data on UK companies over the period 1994-2003. Following Ackerberg et al. (2005) we adjust the algorithm in Olley and Pakes (1996) by augmenting investment and exit decisions to allow for exogenous demand shocks by trade orientation, assuming that labour and capital are state variables, and productivity follows a first-order Markov process. We extend the framework further by allowing exporting to be an additional control variable that is driven by lagged productivity as in Melitz (2003), leading productivity to follow a second-order Markov process. We find that over the period of introduction of the Euro improvements in aggregate productivity were driven by exporters - mainly by market share reallocations away from inefficient and towards efficient export companies. Aggregate productivity also benefited from improvements in productivity of non-exporters but was driven by improvements within companies rather than by market share reallocations. In a period of sustained real exchange rate appreciation both export cleansing and competitive pressure on non-exporters seem to have contributed to improvements of productivity in the UK manufacturing.

JEL Classification: F14, D24

Keywords: productivity dynamics, structural model, trade orientation, manufacturing companies, UK

Corresponding author:

Patrick Paul Walsh

Department of Economics

Trinity College, Dublin

Dublin 2

Ireland

E-mail: ppwalsh@tcd.ie

\footnotetext{
* This research was undertaken in the Institute for International Integration Studies (IIIS), Trinity College, Dublin, as part of the research project "Evaluating the impact of globalisation using micro data". The paper has benefited from discussions with Gautam Gowrisankaran and Ariel Pakes on the Olley and Pakes (1996) estimation algorithm. The paper was presented at EARIE 2005 and to the International Comparative Analysis of Enterprise (micro) Data (CAED) conference organised by the U.S. Bureau of Census, the Federal Reserve Bank of Chicago, and OECD in 2006. We thank participants for their comments.
} 


\section{INTRODUCTION}

The co-existence of exporting with non-exporting companies within 4-digit industries is a strong feature of our UK data. Bernard et al. (2003) outline the same fact for the US. The primary focus of the paper is to embed the role of company trade orientation into our structural estimation algorithm of productivity dynamics within 4-digit UK manufacturing industries. After estimating productivity dynamics for each company we document and analyse the nature of the aggregation over companies by trade orientation in order to understand aggregate productivity movements.

Integrating trade information in productivity estimation is achieved by adapting the algorithm developed in Olley and Pakes (1996). Following Ackerberg et al. (2005) we adjust the Olley-Pakes algorithm to allow exogenous demand shocks by trade orientation to agument investment and exit decisions, assuming that labour and capital are state variables and productivity follows a first-order Markov process. We extend the framework further by allowing exporting to be an additional control variable that is driven by lagged productivity as in Melitz (2003), leading productivity to follow a second-order Markov process. We apply the modified algorithm to an unbalanced panel of UK exporting and non-exporting manufacturing companies, with annual observations for the period 1997-2001, and estimate time varying productivity for companies within each 4-digit industry, over the 1997-2001 period.

Our approach brings together two strands of literature on productivity and exporting. In the first strand, studies estimate company total factor productivity, in a first step, and in a second step they proceed to link productivity to exporting and contributions to aggregate productivity. ${ }^{1}$ It is our view that testing for a relationship between exporting and (unobservable) productivity, ex-post, is admitting that there is information that should have been used in the structural model of the unobservable while estimating the production function. Indeed theory and empirical evidence on selection mechanisms guide us. Melitz (2003) employs sunk costs associated with exporting that lead to high productivity companies selecting to exporting. Indeed, a second strand of empirical literature confirms this. Roberts and Tybout (1997) for Colombia, Bernard and Jensen (2001) for the US, and Bernard and Wagner (2001) for Germany, estimate selection to exporting regressions and document that sunk export-market entry costs seem important enough to generate immense persistence in company export market participation. Our data also confirm this pattern of persistence in export market participation.

\footnotetext{
${ }^{1}$ Bernard and Jensen (1999), Pavcnik (2002), Lopez-Cordova (2002), and Fernandes (2001), for example, apply Olley and Pakes (1996) algorithm to approximate productivity in the first step and correlate it with trade in a second step.
} 
Given this evidence, as argued in Van Biesebroeck (2003), one should allow for trade orientation when estimating the parameters of the production function. ${ }^{2}$ We wish to go a step further, following Ackerberg et al. (2005), by allowing exporting to be an additional control variable that is driven by lagged productivity (Melitz, 2003), leading to a structural model that estimates company productivity dynamics as a second-order Markov process. The model generates consistent estimates of the coefficients on labour and capital, amongst other observables. An unbiased productivity index for exporters and non-exporters is backed out as a residual. Thus, we make a contribution to the efficiency and trade debate, adding new evidence from the UK. ${ }^{3}$

We use OLS, GLS and Olley-Pakes estimators of productivity that do not allow for trade orientation of companies as our counterfactuals. Our estimates of productivity that allow for endogenous trade orientation show clear and persistent differentials in productivity by trade orientation and over-time. Using the Olley and Pakes (1996) decompositions, we are also able to demonstrate that the improvements in aggregate productivity of the UK manufacturing, during the period of introduction of the Euro, was mainly driven by market share reallocations away from inefficient and towards efficient export companies, alongside gains in productivity within nonexporter companies. In a period of sustained real exchange rate appreciation both export cleansing and competitive pressure on non-exporters seem to have increased productivity of the UK manufacturing, see Harris (2001) for a literature review of these mechanisms.

The remainder of the paper is structured as follows. Section 2 provides a brief overview of data. Section 3 outlines our behavioural model and the estimation methodology used in the paper. Our regression results are reported in sections 4 . In section 4 we also undertake our analysis of aggregate productivity while in Section 5 offer conclusions.

\footnotetext{
${ }^{2}$ Van Biesebroeck (2003) and De Loecker (2004) also consider adapting the algorithm developed in Olley and Pakes (1996) to allow for exporting, however, their approaches differ from ours in the way trade orientation information is incorporated into their model of the unobservable.

${ }^{3}$ In summary, the literature on efficiency and exporting comprises several papers covering various countries: Aw and Hwang (1995) and Aw, Chen, and Roberts (2001) on Taiwan; Bernard and Jensen (1995; 1999) on the US; Clerides, Lach and Tybout (1998) on Colombia, Mexico and Morocco; Bernard and Wagner (1997) on Germany; Kraay (1999) on China; Castellini (2001) on Italy; Delgado, Farinas and Ruano (2002) on Spain; Pavcnik (2002) on Chile. On the UK the only existing study that we are aware of is by Girma, Greenaway and Kneller (2004) covering the period 1988-1999. The studies cover a range of time periods and use a variety of methodologies. Importantly, every single study finds that exporters have higher productivity than non-exporters - a relationship that goes beyond size. They also typically find that exporting companies are bigger, more capital intensive and pay higher wages. The literature does disagree on the self-selection versus learning hypothesis. Castellini (2001) reports some evidence suggesting that the productivity of exporting companies may increase with increases in export intensity. For Chinese companies, Kraay (1999) reports evidence of learning by exporting as well as Van Biesebroeck (2003), for exporters in Africa. Interestingly, Girma, Greenaway and Kneller (2004) is the only study that supports the learning hypothesis for a developed market economy - the UK. The evidence in Delgado, Farinas and Ruano (2001) is inconclusive and Bernard and Jensen (1995, 1999), Bernard and Wagner (1997), Clerides, Lach and Tybout (1998) and Aw and Hwang (1995) explicitly test for but fail to find any evidence to support the learning by exporting hypothesis.
} 
According to Bureau van Dijk, FAME is the most comprehensive database of UK companies available. Data cover all companies filing at the Companies House in the UK and information comprises detailed financial statements, ownership structure, activity description, direct exports, various financial ratios and credit scores. ${ }^{4}$ The dataset used in our analysis contains annual records on more than 80,000 manufacturing companies over the period 1997-2001. The coverage of the data compared to the aggregate statistics reported by the UK Office for National Statistics is as follows: sales - 86\%, employment - 92\%, and exports - 100\%. The manufacturing sectors are identified on the bases of the current 2003 UK SIC at the 4-digit level and range between 1513 and 3663. All nominal monetary variables are converted into real values by deflating with the appropriate 4-digit UK SIC industry deflators taken from the Office for National Statistics. We use PPI to deflate sales and cost of materials, and asset price deflators for capital and fixed investment variables. ${ }^{5}$

The descriptive statistics reported in Table 1 are calculated from the FAME sample of manufacturing companies on the basis of company averages. We first look at the prevalence of exporting among UK manufacturing companies. At one extreme, companies could export the same share of their total output. At the other, a few giant companies would account for all exports. In fact, out of roughly 80,000 companies in the original sample only 15.6 percent report export sales over the period of analysis.

Previous work has sought to link trade orientation with industry. It turns out that exporting companies are quite spread out across industries. Figure 1 plots the distribution of industry export intensity: each of the 215, 4-digit manufacturing industries represented in the sample is placed in one of the 10 bins according to the percentage of companies in the industry that export. In almost all the industries, the fraction of companies that export lies between 10 and 50 percent. Hence, knowing what industry a company belongs to would not answer with sufficient certainty whether it exports. This fact, similar to the findings of Bernard et al. (2003) for the US manufacturing, suggests that industry has less to do with exporting than standard trade models might suggest.

\footnotetext{
${ }^{4}$ FAME is a combination of high quality information from Jordans with easy to use software which has been developed by Bureau van Dijk Electronic Publishing (BvD). The financial breakdown of the companies in the different FAME modules is as follows: FAME A - Turnover $>£ 1.5$ million or Profits $>£ 150,000$ or Shareholder Funds $>£ 1.5$ million; FAME B - Turnover $>£ 500,000$ and $<£ 1.5$ million or Shareholder Funds $>£ 500,000$ and $<£ 1,500,000$ or Fixed Assets or Current Assets or Current Liabilities or Long Term Liabilities > £500,000; FAME C - Fixed Assets or Current Assets or Current Liabilities or Long Term Liabilities $>£ 150,000$ and $<£ 500,000$; recently formed companies and other companies where full financial information is not available are also included in this module.

${ }^{5}$ Katayama, Lu, and Tybout (2003), and related studies, argue that as production functions should be a mapping of data on inputs and outputs, studies using revenues and expenditure data as proxies would produce biased productivity measures. As in this study, most use industry level deflators for output, raw material and capital assets to get back the quantity data needed. It is clear that inputs and outputs can be priced differently for exporters and non-exporters within narrowly defined industries. We note, however, that allowing for endogenous trade orientation in the unobservable will control, to a certain degree, for persistent exchange rate adjusted pricing gap between exporters and non-exporters in their use of inputs and their outputs within 4-digit industries. Time dummies can control for movements in the real effective exchange rate over-time within exporting and non-exporting samples.
} 
Not only are companies heterogeneous in whether they export, they also differ substantially in various crude measures of productivity. Table 1 reports mean differences, segregating exporters from non-exporters, and standard deviations characterising the distributions across companies of value added per worker relative to the overall mean. Similarly, the distributions across exporting and non-exporting companies of value added per worker relative to the 4-digit industry mean are characterised. While differences across industries certainly appear in the data, what is surprising is how little industry explains about exporting and productivity. Hence, a satisfactory explanation of company level behaviour must go beyond the industry dimension. Therefore, we consequently pursue an explanation of these facts that bypasses industries and goes directly to samples defined by trade orientation at the company level.

Table 1 also shows the importance of export markets for the companies that do export. Interestingly, the vast majority of exporters export less than 30 percent of what they produce. Less than 10 percent of the exporting companies export more than 70 percent of their production. Even for the minority of companies that do export, domestic sales dominate. An answer to these facts is documented in Table 1 - exporters are much larger. They are almost 4 times the size of nonexporting companies on average, even when export revenues are excluded from the calculation. While only 15.6 percent of manufacturing companies report that they consistently export, these companies account for almost 75 percent of the output of UK manufacturing.

In this paper our goal is to estimate total factor productivity (TFP) in a consistent manner, to document the TFP gaps and to cast light on the nature of these gaps between exporters and nonexporters, within 4-digit industries. In addition we try to explain movements in aggregate productivity. The strategy of our empirical analysis implies that we will run regressions within 4digit industries, by sub-samples defined according to company export status. This leaves us with the 41 largest 4-digit industries, with sufficient number of observations to run regressions for exporting and non-exporting sub-samples. These largest 4-digit industries account for almost 80 percent of the UK manufacturing sales in our data. In terms of the smallest estimated sample, after lags are applied and observations with missing values deleted, there are 24,338 remaining observations for 6,722 companies. The coverage of the data from this sample compared to the aggregate statistics is $58 \%$ for exports, and 56\% for employment. The correlations between the aggregate statistics series and the estimated sample series are as follows: value added (used in the regressions as dependent variable) - 0.94, employment - 0.97, exports - 0.95 . 
In Table 2 we document summary statistics of regression variables. Exporting companies are older, bigger in terms of value added, employment and capital, and invest more. ${ }^{6}$ The detailed definitions of regression variables are as follow: Value added is total annual sales adjusted for changes in inventories, minus material costs in thousands of pounds sterling. We assume that materials used are in a constant proportion of output. Exports is the reported value of direct exports, in thousands of pounds sterling, recorded annually. The problem of potential undercounting, due to the fact that indirect exports are not included in this measure is discussed in Bernard and Jensen (1995). Labour is full-time equivalent number of employees, recorded annually. Age is constructed by using year of incorporation as a starting point. Capital is measured as total fixed assets by book value, in thousands of pounds sterling, recorded annually. Investment is constructed from the annually observed (for each period, $t$ ) capital stock, $K$ and depreciation, $\delta$ using the perpetual inventory method: $I_{t}=K_{t+1}-(1-\delta) K_{t}$.

\section{BeHAVIOURAL FrameWORK AND Estimation METHODOLOGY}

To estimate productivity we relay on a behavioural framework which builds on models of industry dynamics by Ericson and Pakes (1995) and Hopenhayn (1992) with applications to firm export decisions as in Melitz (2003). Alongside the econometric modelling ideas in Ackerberg et al. (2005), the framework underlines our estimation strategy and helps us specify timing and relational assumptions for the company decisions in a manner similar to Olley and Pakes (1996). ${ }^{7}$

The innovation in our approach is that we extend the Olley and Pakes (1996) framework by explicitly allowing market structure (factor markets, demand conditions and prices) to differ across exporting and non-exporting companies. Furthermore, we relax the often criticised assumption about labour being variable and non-dynamic input, i.e., that the choice of labour in period $t$ has no implications for the future of the company choices. Considering the feature of the labour markets in developed European countries with strong employment protection laws, it is unlikely that hiring decisions do not have long-term implications for the company.

\subsection{Estimation methodology assuming exogenous exporting}

As in Olley and Pakes (1996) the log-linear production function to be estimated is

$$
y_{j t}=\beta_{0}+\beta_{k} k_{j t}+\beta_{a} a_{j t}+\beta_{l} l_{j t}+\omega_{j t}+\eta_{j t},
$$

\footnotetext{
${ }^{6}$ It is worth noting that export status is persistent over time as only 9 percent of exporting companies switch between exporting and non-exporting states, in our sample during the period of analysis. We mark a company as an exporter if we observe in the data exporting by the company in any year within a 3-year moving window.

${ }^{7}$ Levinsohn and Petrin (2003) modify the Olley and Pakes (1996) approach by using intermediate inputs, such as electricity or fuel usage instead of investment which have the advantage of more efficient use of the data. See Ackerberg et al. (2005) for a critique of this approach.
} 
where the log of company $j$ 's value added at time $t, y_{j t}$, is modelled as a function of the logs of that company's state variables at $t$, namely age, $a_{j t}$, capital, $k_{j t}$, and labour, $l_{j t}$.

Investment demand, $i_{j t}$ determines the capital stock at the beginning of each (next) period. The law of capital accumulation is given by $k_{j t+1}=(1-\delta) k_{j t}+i_{j t}$. The error structure is comprised of a stochastic component, $\eta_{j t}$, with zero expected mean, and a component that represents unobserved productivity, $\omega_{j t}$. Both $\omega_{j t}$ and $\eta_{j t}$ are unobserved, but $\omega_{j t}$ is a state variable, and thus affects company's choice variables. On the other hand $\eta_{j t}$ has zero expected mean given current information, and hence does not affect decisions.

Company's single period profit function is $\pi\left(k_{j t}, a_{j t}, l_{j t}, \omega_{j t}, e_{j t}\right)-c\left(i_{j t}, e_{j t}\right)$, where both $\pi($. and $c\left(\right.$.) depend on $e_{j t}$, which represents the economic environment that companies face at a particular point in time; $e_{j t}$ could capture input prices, characteristics of the output market, or industry characteristics. As in Olley and Pakes (1996) all these factors are allowed to change over time; importantly, in our extension we allow the factors to also vary across companies according to their exporting status. Including market structure variation in the state space reflects some of the competitive richness of the Markov-perfect dynamic oligopoly models such as Ericson and Pakes (1995).

The company maximizes its expected value of both current and future profits according to

$V\left(k_{j t}, a_{j t}, l_{j t}, \omega_{j t}, e_{j t}\right)=\max \left\{\begin{array}{c}\Phi\left(k_{j t}, a_{j t}, l_{j t}, \omega_{j t}, e_{j t}\right), \\ \max _{i_{j t} \geq 0}\left\{\pi\left(k_{j t}, a_{j t}, l_{j t}, \omega_{j t}, e_{j t}\right)-c\left(i_{j t}, e_{j t}\right)+\right. \\ \left.\beta E\left[V\left(k_{j t+1}, a_{j t+1}, l_{j t+1}, \omega_{j t+1}, e_{j t+1}\right) \mid k_{j t}, a_{j t}, l_{j t}, \omega_{j t}, e_{j t}, i_{j t}\right]\right\} .\end{array}\right.$

The Bellman equation explicitly considers two company decisions. First is the exit decision; $\Phi\left(k_{j t}, a_{j t}, l_{j t}, \omega_{j t}, e_{j t}\right)$ represents the sell-off value of the company. Second is the investment decision, $i_{j t}$, which solves the interior maximization problem. Under the assumption that equilibrium exists and that the difference in profits between continuing and exiting is increasing in $\omega_{j t}$ we can write the optimal exit decision rule as

$$
\mathrm{X}_{j t}=\left\{\begin{array}{ccc}
1 & \text { if } & \omega_{j t} \geq \bar{\omega}_{t}\left(k_{j t}, a_{j t}, l_{j t}\right) \\
0 & \text { otherwise }
\end{array}\right.
$$

and the investment demand function as,

$$
i_{j t}=i_{t}\left(k_{j t}, a_{j t}, l_{j t}, \omega_{j t}, e_{j t}\right) \text {. }
$$

Productivity, $\omega_{j t}$ is assumed to be determined by a family of distributions conditional on the information set at time $t-1, J_{t-1}$, which includes past productivity shocks. Given this set of distributions, both the exit and investment decisions will crucially hinge upon the companies' perceptions of the distribution of future market structure conditional on current information (past productivity). The decisions that the companies take will in turn generate a distribution for the 
future market structure (Maskin and Tirole, 1988). In our behavioural framework we explicitly introduce trade orientation by companies in $e_{j t}$. Decisions on whether to invest and to exit the market will depend explicitly on whether a companies exports or not. From the summary statistics of our data (Table 2) and the findings of numerous empirical studies we know that exporters invest more per worker and are also less likely to exit compared to non-exporting companies. ${ }^{8}$

A fundamental problem afflicting investment and thus productivity measurement is that companies are made up of different product mixes. In the absence of product-specific data, which is a typical problem for micro datasets available, consistent estimates of company productivity can be obtained by allowing the parameters of the production technology to vary across companies making different (types of) products. The identifying information that we use here to sort companies by product types is the companies' exporting status. As argued above, exporters differ from nonexporters by both the production techniques they employ and the demand characteristics they face.

Since we deflate value added with an industry-wide PPI, we do not control for the fact that output and factor prices might be different and/or evolve differently over time for exporting and non-exporting companies. Therefore we drop this assumption and incorporate the exporting information in the investment and survival equilibrium equations. More formally, we explicitly allow that exporting companies face differential market structures and factor prices when decisions are made about investment and exit from the market.

Pakes (1994) discusses conditions under which the investment demand function (equation (4)) is strictly monotonic in $\omega_{j t}$. Under such conditions investment can be inverted to generate $\omega_{j t}=h_{t}\left(i_{j t}, e_{j t}, k_{j t}, a_{j t}, l_{j t}\right)$.

Then substituting equation (5) into the production function (1) gives us,

$y_{j t}=\beta_{0}+\beta_{k} k_{j t}+\beta_{a} a_{j t}+\beta_{l} l_{j t}+h_{t}\left(i_{j t}, e_{j t}, k_{j t}, a_{j t}, l_{j t}\right)+\eta_{j t}$.

Equation (6) can be estimated as in Olley and Pakes (1996) with semi-parametric methods that treat the inverse investment function $h_{t}($.) non-parametrically, using either polynomial or kernel. The non-parametric treatment, however, results in collinearity and requires the constant, $k_{j t}, a_{j t}$ and $l_{j t}$ terms to be combined into function $\phi_{t}\left(i_{j t}, e_{j t}, k_{j t}, a_{j t}, l_{j t}\right)$ such that equation (6) becomes $y_{j t}=\phi_{t}\left(i_{j t}, e_{j t}, k_{j t}, a_{j t}, l_{j t}\right)+\eta_{j t}$.

It is important to note that the ability to invert investment depends not only on the strict monotonicity in $\omega_{j t}$ but also on the fact that $\omega_{j t}$ is the only unobservable in the investment equation. This scalar unobservable assumption implies that there can be no measurement error in the

\footnotetext{
${ }^{8}$ Note that the investment policy function in Olley and Pakes (1996) is a solution to a complicated dynamic programming problem and depends on all the primitives of the model like demand functions, the specification of sunk costs, form of conduct in the industry and other factors as recently clarified by Ackerberg et al. (2005). All these factors are allowed here to be different and evolve differently over time, for exporting and non-exporting companies.
} 
investment equation, no unobserved differences in investment costs across companies and no unobserved separate factors that affect investment across companies but not production. By introducing exporting information in the investment function we are able to control for such differences and to relax the above assumptions. In section 3.2 we relax the scalar unobservable assumption following Ackerberg et al. (2005) and further discuss implications for our estimation algorithm.

The capital, age and labour coefficients are identified in the second stage of the Olley-Pakes procedure. First, note that even though we do not identify any input coefficients in the first stage we are able to estimate $\hat{\phi}_{t}$ for use in the second stage. We express $\omega_{j t}$ as $\hat{\omega}_{j t}=\hat{\phi}_{j t}-\beta_{0}-\beta_{k} k_{j t}-\beta_{a} a_{j t}-\beta_{l} l_{j t}$. Second, the first stage of the Olley-Pakes procedure is not affected by endogenous selection because $\phi_{t}$ fully controls for the unobservable; by construction, $\eta_{j t}$ represents unobservables that are not known by the company before input and exit decisions are made. In contrast, the second stage of the estimation procedure is affected by endogenous exit. From equation (3) it is evident that the exit decision in period $t$ depends directly on $\omega_{j t}$. Using the assumption that $\omega_{j t}$ follows an exogenous first-order Markov process, we can decompose $\omega_{j t}$ into its conditional expectation given the information known by the company at $t-1$ and a residual:

$$
\begin{aligned}
\omega_{j t} & =E\left[\omega_{j t} \mid J_{j t-1}\right]+\xi_{j t} \\
& =E\left[\omega_{j t} \mid \omega_{j t-1}\right]+\xi_{j t} \\
& =g\left(\omega_{j t-1}\right)+\xi_{j t} .
\end{aligned}
$$

By construction $\xi_{j t}$ is uncorrelated with $J_{j t-1}$ and thus with $k_{j t}, a_{j t}$ and $l_{j t}$ which are functions of only the information set at time $t$-1. Next from equation (1) and substituting equation (8) above we can write

$$
y_{j t}=\beta_{0}+\beta_{k} k_{j t}+\beta_{a} a_{j t}+\beta_{l} l_{j t}+g\left(\omega_{j t-1}\right)+\xi_{j t}+\eta_{j t} .
$$

Now to correct for endogenous selection (exit) lets take expectations of equation (9) conditional on both the information at $t-1$ and on $\mathrm{X}_{j t}=1$ (i.e., surviving till the next period). We can write

$$
\begin{aligned}
E\left[y_{j t} \mid J_{j t-1}, X_{j t}=1\right] & =\beta_{0}+\beta_{k} k_{j t}+\beta_{a} a_{j t}+\beta_{l} l_{j t}+E\left[\omega_{j t} \mid J_{j t-1}, X_{j t}=1\right] \\
= & \beta_{0}+\beta_{k} k_{j t}+\beta_{a} a_{j t}+\beta_{l} l_{j t}+g\left(\omega_{j t-1}, \bar{\omega}_{t}\left(k_{j t}, a_{j t}, l_{j t}\right)\right) .
\end{aligned}
$$

We do not directly observe $\bar{\omega}_{t}\left(k_{j t}, a_{j t}, l_{j t}\right)$ and to control for it we use data on observed exit. This means that the probability of being in the data at period $t$ conditional on information known at $t-1$ is:

$$
\begin{aligned}
\operatorname{Pr}\left(X_{j t}=1 \mid J_{j t-1}\right) & =\operatorname{Pr}\left(\omega_{j t} \geq \bar{\omega}_{t}\left(k_{j t}, a_{j t}, l_{j t}\right) \mid J_{j t-1}\right) \\
& =\varphi_{t}^{\prime \prime}\left(\omega_{j t-1}, \bar{\omega}_{t}\left(k_{j t}, a_{j t}, l_{j t}\right)\right)=\varphi_{t}^{\prime}\left(\omega_{j t-1}, k_{j t}, a_{j t}, l_{j t}\right) \\
& =\varphi_{t}\left(i_{j t-1}, e_{j t-1}, k_{j t-1}, a_{j t-1}, l_{j t-1}\right)=P_{j t} .
\end{aligned}
$$


Equation (11) represents the second step of our estimation algorithm and can be estimated nonparametrically using probit model with a $\left(4^{\text {th }}\right.$-order $)$ polynomial or kernel as in Olley and Pakes (1996). Note that we extend the state variable set with exporting status information which is an important determinant of companies' decision to exit. For a company characterised by $\left(i_{j t-1}, e_{j t-1}, k_{j t-1}, a_{j t-1}, l_{j t-1}\right)$ we are able to generate a consistent estimate of the probability of the company surviving to period $t, \hat{P}_{j t}$. As long as the density of $\omega_{j t}$ given $\omega_{j t-1}$ is positive in the area around $\bar{\omega}_{t}\left(k_{j t}, a_{j t}, l_{j t}\right)$, we can invert to write $\bar{\omega}_{t}\left(k_{j t}, a_{j t}, l_{j t}\right)$ as a function of $\omega_{j t-1}$ and $P_{j t}$ : $\bar{\omega}_{t}\left(k_{j t}, a_{j t}, l_{j t}\right)=f\left(\omega_{j t-1}, P_{j t}\right)$.

Substituting this equation into equation (10) and using expressions for estimated valus, $\hat{\omega}_{j t-1}$

and $\hat{P}_{j t}$ gives us

$$
\begin{aligned}
E\left[y_{j t} \mid J_{j t-1}, X_{j t}=1\right] & =\beta_{0}+\beta_{k} k_{j t}+\beta_{a} a_{j t}+\beta_{l} l_{j t}+g\left(\omega_{j t-1}, f\left(\omega_{j t-1}, P_{j t}\right)\right) \\
= & \beta_{0}+\beta_{k} k_{j t}+\beta_{a} a_{j t}+\beta_{l} l_{j t}+g^{\prime}\left(\omega_{j t-1}, P_{j t}\right) \\
= & \beta_{0}+\beta_{k} k_{j t}+\beta_{a} a_{j t}+\beta_{l} l_{j t}+g^{\prime}\left(\hat{\phi}_{j t-1}-\beta_{0}-\beta_{k} k_{j t-1}-\beta_{a} a_{j t-1}-\beta_{l} l_{j t-1}, \hat{P}_{j t}\right),
\end{aligned}
$$

which after removing the expectations operator becomes

$y_{j t}=\beta_{k} k_{j t}+\beta_{a} a_{j t}+\beta_{l} l_{j t}+g^{\prime \prime}\left(\hat{\phi}_{j t-1}-\beta_{k} k_{j t-1}-\beta_{a} a_{j t-1}-\beta_{l} l_{j t-1}, \hat{P}_{j t}\right)+\xi_{j t}+\eta_{j t}$,

where the two $\beta_{0}$ terms have been encompassed into the non-parametric function $g$ ”. Equation (12) represents the third (last) step of our estimation algorithm and can be estimated with NLLS, approximating $g$ " with either polynomial or kernel. It is also important to note that the identification of the labour coefficient in the last rather than in the first step of the algorithm requires making assumptions how current labour responds to the current realisations of $\xi_{j t}$. One possible treatment is that labour is fixed before the realisation of $\xi_{j t}$, which is the same assumption as for capital. This implies that current labour is not correlated with current innovation in productivity and $\beta_{l}$ can be identified in the third step. A second, and more realistic, assumption is that current labour can respond to current innovations in productivity. We still can obtain estimates of $\beta_{l}$ using equation (12) and the fact that lagged values of labour $\left(l_{j t-1}\right)$ should be uncorrelated with $\xi_{j t}$ which follows from the information structure of the model.

\subsection{Estimation methodology assuming endogenous exporting}

The assumption of a scalar unobservable state variable can be relaxed. In the preceding analysis we discuss how introducing exporting information results in relaxing the original Olley-Pakes assumption in two ways. First, we allow investment to depend on an unobservable demand shock that varies across companies according to their exporting status, in addition to the $\omega_{j t}$ process. If we assume that the demand shock, $\alpha_{j t}$, also follows a first-order Markov process, independent of the 
process $\omega_{j t}$ then the investment function will be a function of both unobservables: $i_{j t}=i_{t}\left(k_{j t}, a_{j t}, l_{j t}, \omega_{j t}, \alpha_{j t}\right) .{ }^{9}$ Using the exporting information as a control together with observed investments allows us to substitute for $\omega_{j t}$ in the first step of the estimation algorithm. Specifically, it is reasonable to assume that the exporting information contains companies' pricing decisions. If we label the bivariate policy function $\left(i_{j t}, e_{j t}\right)$ as $\Psi_{t}$ and assume as in Ackerberg et al. (2005) that it is bijecture in $\left(\omega_{j t}, \alpha_{j t}\right)$ conditional on $\left(k_{j t}, a_{j t}, l_{j t}\right)$, the policy function can be inverted to form $\omega_{j t}=\Psi_{t}^{-1}\left(k_{j t}, a_{j t}, l_{j t}, i_{j t}, e_{j t}\right)$. Then we can proceed with the first step of estimation as in section 3.1.

For the third step, since $\alpha_{j t}$ progresses independently of $\omega_{j t}$ the company's conditional expectation of $\omega_{j t}$ given $J_{j t-1}$ only depends on $\omega_{j t-1}$. Thus the third step can again be specified as equation (12). The advantage of using exporting information (interpreted here as a control for demand shocks) besides being an important determinant of investment also generates independent variance in $\hat{\phi}$ and thus improves the precision of our estimates.

However, assuming that exporting status of the company is completely independent process from the evolution of $\omega_{j t}$ is not satisfactory. Besides demand side, information for exporting status is related to important supply side characteristics. A large number of empirical studies show that there is a strong selection mechanism where more productive companies enter foreign markets. Melitz (2003) builds this stylised fact into a theoretical model of firm productivity and trade orientation. Thus, a more realistic assumption is that a company's exporting status at time $t$ depends on the company's productivity in previous periods. These considerations also suggest that productivity follows more complicated process than previously assumed. We implement this fact through a second-order Markov process describing productivity. The investment demand equation then becomes: $i_{j t}=i_{t}\left(\omega_{j t}, \omega_{j t-1}, k_{j t}, a_{j t}, l_{j t}\right)$. The presence of two unobservables complicates invertability of the investment equation and requires additional assumptions. The solution relies on again using a second observable control of the company decision problem. The control that we use is the company's exporting status, which can be interpreted as an indicator of company's investment in developing higher quality products, advertising, and building distribution networks in foreign markets. Then we can formulate as in Ackerberg et al. (2005) the bivariate policy function:

\footnotetext{
${ }^{9}$ It is also reasonable to assume that there are two Markov processes that are interrelated. The company's conditional expectation of $\omega_{j t}$ given $J_{j t-1}$ then depends on both $\omega_{j t-1}$ and $\alpha_{j t-1}$. The informational demand in this case is much higher though. We will need then to estimate $\alpha_{j t-1}$ using detailed demand side data as in Berry et al. (1995) which we do not have.
} 
$\left(\begin{array}{c}i_{j t} \\ e_{j t}\end{array}\right)=\Psi_{t}\left(\omega_{j t}, \omega_{j t-1}, k_{j t}, a_{j t}, l_{j t}\right)$. Under certain conditions the $\Psi_{t}$ can be inverted in $\omega_{j t}$ to obtain $\omega_{j t}=\Psi_{t}^{-1}\left(i_{j t}, e_{j i}, k_{j t}, a_{j t}, l_{j t}\right)$.

However, we can also interpret exporting status as a state variable representing the company's technology, i.e., the stock of higher quality products, know-how, and distribution networks in foreign markets. The company's technological and logistic assets evolve as a result of decisions, affected by the observed productivity in previous periods. Furthermore, the exporting status will also be affected by other company-specific factors such as type of ownership and corporate governance which generally should not be correlated with the investment decisions but may affect demand. Following the argument we can specify the current exporting status as a nonparametric function of $i_{j t-1}, k_{j t-1}, a_{j t-1}, l_{j t-1}$ and a vector of other company-specific characteristics, $X^{\prime}{ }_{j t}$ such as type of ownership and corporate governance. Estimating an exporting equation and using the propensity to export, $\hat{e}_{j i}$ as a control instead of $e_{j i}$ allows as to treat the export decision as an endogenous one. This treatment also implies that we implicitly consider two sources of productivity growth, one evolving as a controlled Markov process, and one as an exogenous Markov process. This is the closest empirical approximation of our behavioural framework.

The first step of our estimation algorithm remains the same as before - the non-parametric function controlling for current productivity is specified as a polynomial, including the exporting information. The third step is modified and now becomes

$y_{j t}=b_{k} k_{j t}+b_{a} a_{j t}+g^{\prime \prime}\left(\hat{\phi}_{j t-1}-b_{k} k_{j t-1}-b_{a} a_{j t-1}-b_{l} l_{j t-1}, \hat{\phi}_{j t-2}-b_{k} k_{j t-2}-b_{a} a_{j t-2}-b_{l} l_{j t-2}, \hat{\tilde{P}}_{j t}\right)+\xi_{j t}+\eta_{j t}$,

where $\hat{\phi}$ variables are obtained from the first stage estimates at $t-1$ and $t$-2 periods. Because the conditional expectation of $\omega_{j t}$ given $J_{j t-1}$ now depends on $\omega_{j t-1}$ and $\omega_{j t-2}$, we need to use estimates of $\hat{\phi}$ from two prior periods.

Controlling for endogenous selection has to be modified accordingly as well; note the change of notation ( $\hat{\tilde{P}}_{j t}$ instead of $\hat{P}_{j t}$ ). Thus, the second-step equation (11) will become

$$
\begin{aligned}
\tilde{P}_{j t} & =\tilde{\varphi}_{t}^{\prime \prime}\left(\omega_{j t-1}, \omega_{j t-2}, \bar{\omega}_{t}\left(k_{j t}, a_{j t}, l_{j t}\right)\right)=\tilde{\varphi}_{t}^{\prime}\left(\omega_{j t-1}, \omega_{j t-2}, k_{j t}, a_{j t}, l_{j t}\right) \\
& =\tilde{\varphi}_{t}\left(i_{j t-1}, i_{j t-2}, e_{j t-1}, e_{j t-2}, l_{j t-1}, l_{j t-2}, k_{j t-2}, a_{j t-2}\right)
\end{aligned}
$$

where the second equality holds because of equation (5) and the fact that $k_{t}$ and $a_{t}$ are deterministic functions of $i_{t-1}, k_{t-1}$, and $a_{t-1}, k_{t-1}$ and $a_{t-1}-$ of $i_{t-2}, k_{t-2}$, and $a_{t-2}$, etc.

In terms of verifying whether entering foreign markets makes companies more productive, we have filtered out market structure specific shocks that are different for exporters (like demand conditions, factor markets, exit barriers, etc.) and do not attribute them to productivity gains by 
exporters. ${ }^{10}$ However, these factors remain constant across exporters within a given industry and a time period. On a more conceptual level, market conditions might just be one of the driving forces behind the learning process. So if we still find evidence for productivity gains by exporters, it would mean that additional company-specific factors play a significant role in making exporters more productive once they have started exporting, e.g., contacts with foreign buyers, location, destination of exports. Note that this effect is purified from differences in price trends, factor prices, and market conditions common to all exporters within an industry.

\section{Estimation Results and Analysis of Aggregate Productivity}

We run separate regressions for each of the top 41 4-digit industries. In Table 3 we report weighted averages, using value added as weight, of the estimated coefficients from these regressions. In addition, we also report weighted averages, using value added as weight, of log company level productivity, $\omega$, with and without the first step regression error for results form all estimators used. We compute productivity measures aggregating over exporting and non-exporting sub-samples and over 4-digit industries, first, where productivity at the company level contains the regression error by company. In the second productivity measure the first step regression error is deducted such that we are left with the pure deterministic part of TFP, i.e., $\omega$. The difference between the two measures is very small and we further focus our discussion on the productivity measure containing the regression error, which can be interpreted as stochastic learning process.

First, in Table 3 we report our regressions where export status of a company is not considered. In this context we report OLS, GLS (within group), and the standard Olley-Pakes (without exporting information) estimators, columns 2, 3 and 4, respectively. These can be compared to the Olley-Pakes estimators, where export status is treated as an exogenous shock to investment and exit decisions, column 5 , and where export status is considered to be a control variable that leads to a second-order Markov process in productivity - column $6 .{ }^{11}$ In columns 7 and 8 we repeat the previous two estimations where we use instrumented probabilities of being an exporter instead of export status.

Finally, we split exporters and non-exporters into sub-samples within industries, allowing for differential technology and factor shares, treating the probability of being an exporter

\footnotetext{
${ }^{10}$ Introducing the exporting information into the production function can be treated as introducing an additional input in production. If one has to identify the coefficient on the exporting input in the third step, it would imply that exporting only affects the average of the future productivity distribution and hence leaves no scope for learning by exporting to be a heterogeneous process across companies. In addition it would imply that the effect is time-invariant, i.e. every year exporting raises output (conditioned on labour and capital) by the coefficient estimated on exporting.

${ }^{11}$ The standard errors of all Olley-Pakes estimation routines are bootstrapped using 1,000 replications.
} 
(conditional on company characteristics) as an exogenous shock to investment and exit decisions and alternatively, as an endogenous control variable leading to a second-order Markov process in productivity - columns 9 to 12, respectively. By comparing results from OLS and GLS with the Olley-Pakes estimators we see plausible (and expected) changes in the estimates of the parametric beta's and in productivity, $\omega$. The $\mathrm{R}^{2}$ on the explained movements in value added progressively increases as we incorporate a richer model of the unobservable. In columns (6) and (8) we allow export status and the proability of being an exporter to be considered a control variable that leads to a second-order Markov process in productivity. This changes the beta's and the average and variance in our company level productivity, $\omega$, estimates. In columns (11) and (12) we go further by allowing the parametric technologies to be different across subsamples of non-exporters and exporters, where we allow the proability of being an exporter to be considered a control variable that leads to a second-order Markov process in productivity

Armed with these various estimates of our company level productivity, $\omega$, we analyse the contributions of exporters and non-exporters to aggregate productivity. In the UK manufacturing there is a strong positive correlation (correlation coefficients ranging around 80\%) between export intensity - the ratio of exports to total sales - and aggregate productivity, measured on the basis of various company TFP measures, over the period of analysis as illustrated in Figure 2. OP is the benchmark TFP measure derived from Olley-Pakes estimator where no export-status information is used; OPex1 is the TFP measure derived from an estimation over companies where we allow for exogenous trade orientation shocks and where productivity is first-order Markov process; OPex2 is the TFP measure derived from an estimation over companies where endogenous exporting decisions create a second-order Markov process. Next, xOPex1 denotes a TFP measure estimated separately over sub-samples of exporters and non-exporter where $\omega$ was modelled as a first-order endogenous (instrumenting the export variable with predicted value) Markov process. Analogously, xOPex2 is a TFP measure estimated under the assumption that endogenous exporting leads to a second-order endogenous Markov process.

The relationship between export intensity and TFP depicted in Figure 2 may lead one to think that recent improvements in productivity are export lead (Beckerman, 1965; Kaldor, 1970). Yet, micro-data studies such as Barnes and Haskel (2000; 2001) and Disney et al. (2003) indicate that the expansion of more efficient companies accounted for between one third and a half of the labour productivity growth in the UK during the 1990s and even for a larger share of TFP growth.

To relate industry-level productivity to trade orientation, we start by defining industry productivity, $P_{t}$, as a market-share weighted sum of the company productivity levels: $P_{t}=\sum_{i} s_{i t} \omega_{i t}$, where $\omega_{i t}$ is company productivity as defined in previous sections and $s_{i t}$ is the value of company $i$ 's 
real revenue relative to total industry revenue in year $t$. With this formulation, shifts of output from low productivity to high productivity companies will contribute positively to industry productivity growth, even if no individual company experiences a productivity increase. This analysis is appropriate because our ultimate interest is in the ability of the companies in the industry to convert the set of inputs used in the industry into output, and movements of resources from low to high productivity companies can be just as effective in increasing industry output as are productivity improvements within individual companies. As shown by Olley and Pakes (1996), aggregate productivity can be rewritten as: $P_{t}=\bar{P}+\sum_{i} \Delta s_{i t} \Delta \omega_{i t}$, where $\bar{P}$ is the unweighted mean productivity over all companies in a particular industry, in year $t$ and the $\Delta$ is used to represent a deviation from the un-weighted mean in year $t$. The second term in the equation is the sample covariance between company productivity and market share in year $t$, and summed up over the number of companies in the year. The larger this covariance, the higher the share of output that is allocated to more productive companies and the higher is industry productivity.

Table 4 reports the changes in aggregate productivity for each of the eleven aggregate (2digit) industries over the 1997-2001 period as the decompositions of aggregate productivity change is reported separately for exporters and non-exporters. We report decompositions of aggregate productivity based on five productivity measures corresponding to the original Olley-Pakes algorithm (OP) and to our modified estimation algorithm where we use exporting information and model the exporting status as a first- or second-order Markov process, while estimating the total sample (OPex1 and OPex2) and the exporter and non-exporter sub-samples separately (xOPex1 and xOPex2). Furthermore, we report separate decompositions of aggregate productivity for two distinct periods, before (for 1997-98) and after (for 2000-01) the implementation of the Euro, in the beginning of 1999. By looking in changes of aggregate productivity in the two periods with distinct exchange rate regimes and international trade conditions we are able to derive important results concerning the impact of foreign trade and macroeconomic conditions on productivity.

Interestingly, we find a dual pattern, which certainly is not export driven. For the exporter sample (containing more productive companies), market share expansion drives aggregate productivity, rather than productivity improvements within companies as shown in Table 4, columns 4 to 7. Such aggregate outcomes can be explained by mechanisms outlined in the Melitz (2003) model, driven by micro selection and market share reallocation effects. For the non-exporter sample (containing less productive companies), the pattern is quite the opposite - within company productivity change is larger than the productivity change due to market share reallocations. This evidence suggests that there is not much learning by exporting but rather less productive companies 
tend to improve their productivity in an attempt to converge to the more productive exporting companies. One would be wrong to assume that TFP is export lead in the traditional sense.

Looking into the patterns of specific industries, we notice that there are interesting differences between exporter and non-exporter samples as well as with respect to time periods, before and after the implementation of the Euro. For exporters the relocation of market shares (column 6 vs. column 7) plays more important role in the changes of aggregate productivity compared to non-exporters. Furthermore, a general pattern across the industries is that aggregate productivity, driven mostly by market share relocation increases more significantly in the post-Euro period. Considering non-exporters, in general, it is evident that the non-exporting companies were loosing productivity in the pre-Euro period while in the period after 1999 there is significant increase in within company productivity (column 10 vs. column 11), which seems to play important role in the changes of the aggregate productivity as well. While increasing their individual productivities, non-exporting companies remained relatively small as there are no significant market share reallocations in the sample. The decompositions of the total manufacturing sample for exporters and non-exporters by time periods confirm the patters observed in individual industries.

Noteworthy is also the fact that the productivity measure, based on the original OP estimation algorithm, without taking into account the company exporting status, leads often to different interpretations about the factors affecting aggregate productivity compared to measures derived on the basis of our modified estimation algorithm. Furthermore, the productivity measures calculated by using exporting information and estimates of the total sample (OPex1 and OPex2) show similar decomposition pattern to the one depicted by productivity measures calculated on the basis of estimates of separate exporter and non-exporter samples (xOPex1 and xOPex2). Importantly, all reported productivity measures where exporting information is incorporated into the estimation algorithm exhibit similar patterns and confirm the robustness of our conclusions concerning the changes in aggregate productivity.

The observed general pattern indicates that in the exporter sample a larger share of industry output is being reallocated to the more productive companies, and thus, industry productivity is higher than the unweighted company mean. Unlike the unweighted mean productivity, the magnitude of covariance term does vary greatly over time and more so for exporters, although the non-exporter sample also exhibits significant reallocations in some industries and periods. This variation in the magnitude of the covariance terms indicates that market share reallocations rather than shifts of the company productivity distribution are the main source of aggregate industry productivity growth observed in Figure 2. It is also important to stress that in the sample of nonexporters, which are the less productive companies in every industry, there is a tendency of within 
company productivity improvements. This pattern suggests a trend toward convergence between exporter and non-exporter samples as the trend strengthens after the implementation of the Euro.

\section{CONCLUSION}

In this paper we outline a methodology for estimating the parameters of a production function while linking the unobservable productivity to an endogenous company level trade orientation choice, amongst other factors. Following Ackerberg et al. (2005) we adjust the algorithm in Olley and Pakes (1996) by augmenting investment and exit decisions to allow for exogenous demand shocks by trade orientation, assuming that labour and capital are state variables, and productivity follows a first-order Markov process. We extend the framework further by allowing exporting to be an additional control variable that is driven by lagged productivity as in Melitz (2003), leading productivity to follow a second-order Markov process. We estimate the parameters of production functions for exporting and non-exporting samples of companies within the 4-digit UK manufacturing industries, for the period 1997 - 2001. Allowing for trade-orientation greatly enhances our ability to obtain consistent and unbiased estimates of the parameters of the production function.

We find that over the period of introduction of the Euro improvements in aggregate productivity were driven by exporters - mainly by market share reallocations away from inefficient and towards efficient export companies. Aggregate productivity also benefited from improvements in productivity of non-exporters but was driven by improvements within companies rather than by market share reallocations. These findings show a dual pattern in aggregate productivity changes and seem to support the idea that a sustained real exchange rate appreciation can induced export (company) cleansing as well as competitive pressure on non-exporters to increase productivity in the UK manufacturing. 


\section{REFERENCES}

Ackerberg, D., Benkard, L., Berry, S., and Pakes, 2005. A. Econometric Tools for Analyzing Market Outcomes, Forthcoming chapter in Handbook of Econometrics, Volume 6.

Aw, B.Y. and Hwang, A.R., 1995. Productivity and the export market: A firm-level analysis. Journal of Development Economics 47, 313-332.

Aw, B.Y., Chen, X., and Roberts, M.J., 2001. Firm-level evidence on productivity differentials and turnover in Taiwanese manufacturing, Journal of Development Economics 66, 51-86.

Barnes, M., and Haskel, J., 2000. Productivity growth in the 1990s: Evidence from British plants, Queen Mary, University of London Draft Paper, available at http://www.qmw.ac.uk/ ugte193.

Barnes, M., and Haskel, J., 2001. Productivity, competition and downsizing. In Summary Volume of Treasury Growth Seminar, presented at No.11 Downing Street, October 2000, HM Treasury, London, March, available at http://www.qmw.ac.uk/ ugte193 and http://www.hm-treasury.gov.uk.

Beckerman, W., 1965. Demand, exports and growth. In W. Beckerman and Associates, The British economy in 1965, pp. 44-72. The National Institute of Economic and Social Research.

Bernard, A., Eaton, J., Jensen, J.B., and Kortum, S., 2003. Plants and productivity in international trade, American Economic Review 93(4), 1268-1290.

Bernard, A. and Jensen, J.B., 1995. Exporters, jobs and wages in U.S. manufacturing, 1976-1987. The Brooking Papers on Economic Activity. Microeconomics 1995, 67-112.

Bernard, A. and Jensen, J.B., 1999. Exporting and productivity, NBER Working Paper No. 7135.

Bernard, A. and Jensen, J.B., 2001. Why some firms export, NBER Working Paper No. 8349.

Bernard, A. and Wagner, J., 1997. Exports and success in German manufacturing, Weltwirtschaftliches Archiv 133, 134-157.

Bernard, A. and Wagner, J., 2001. Export entry and exit by German firms, Weltwirtschaftliches Archiv 137, 105-123.

Berry, S., Levinsohn, J., and Pakes, A., 1995. Automobile process in market equilibrium, Econometrica 63(4), 841-890.

Castellini, D., 2001. Export behaviour and productivity growth: Evidence from Italian manufacturing firms, Universita di Urbino, mimeo.

Clerides, S.K., Lach, S., and Tybout, J.R., 1998. Is learning-by-exporting important? Microdynamic evidence from Colombia, Mexico and Morocco. Quarterly Journal of Economics CXIII, 903-947.

Delgado, M., Farinas, J., and Ruano, S., 2002. Firm productivity and export markets: A nonparametric approach, Journal of International Economics 57, 397- 422. 
De Loecker, J., 2004. Do exports generate higher productivity? Evidence from Slovenia, LICOS Discussion Paper 151/2004, K.U. Leuven.

Disney, R., Haskel, J., and Heden, Y., 2003. Restructuring and productivity growth in UK manufacturing, Economic Journal 113 (July), 666-694.

Ericson, R. and Pakes, A., 1995. Markov-perfect industry dynamics: A framework for empirical work. Review of Economic Studies 62, 53-82.

Fernandes, A., 2001. Trade policy, trade volumes and plant-level productivity in Colombian manufacturing industries, Yale University, mimeo.

Girma, S., Greenaway, D., and Kneller, R., 2004. Does exporting lead to better performance? A microeconometric analysis of matched firms. Review of International Economics 12(5), 855866.

Harris, Richard. G., 2001 “Is There a Case For Exchange-Rate-Induced Productivity

Change?” In Revisiting the Case for Flexible Exchange Rates Proceedings of a Conference, November 2000. (Ottawa: Bank of Canada)

Hopenhayn, H., 1992. Entry, exit, and firm dynamics in long-run equilibrium. Econometrica 60, 1127-1150.

Kaldor, N., 1970. The case for regional policies. Scottish Journal of Political Economy 17, 337348.

Katayama, H., Lu, S., and Tybout, J., 2003.Why plant-level productivity studies are often misleading, and an alternative approach to interference, NBER WP 9617.

Kraay, A., 1999. Exports and economic performance: Evidence from a panel of Chinese enterprises, World Bank, mimeo.

Levinsohn, J. and Petrin, A., 2003. Estimating production functions using inputs to control for unobservables, Review of Economic Studies 70, 317-341.

Lopez-Cordova, J.E., 2002. NAFTA and Mexico’s manufacturing productivity: An empirical investigation using mirco-level data 1993-1999, Inter-American Development Bank, mimeo.

Maskin, E. and Tirole, J., 1988. A theory of dynamic oligopoly: I\&II, Econometrica 56, 549-600.

Melitz, M.J., 2003. Estimating productivity in differentiated product industries, Econometrica 71(6), 1695-1725.

Olley, S. and Pakes, A., 1996. The dynamics of productivity in the telecommunications equipment industry, Econometrica 64(6), 1263-1297.

Pakes, A., 1994. Dynamic structural models, problems and prospects: mixed continuous discrete controls and market interactions. In: Laffont, J.-J., Sims, C. (Eds.), Advances in Econometrics: The Sixth World Congress of the Econometric Society, volume II, Chapter 5. Cambridge University Press, New York, pp. 171- 260. 
Pavcnik, N., 2002. Trade liberalization, exit, and productivity improvements: Evidence from Chilean plants, Review of Economic Studies 69, 245-276.

Roberts, M.J. and Tybout, J.R., 1997. The decision to export in Colombia: An empirical model of entry with sunk costs. American Economic Review 87 (4), 545-564.

Van Biesebroeck, J., 2003. Exporting raises productivity in sub-Saharan African manufacturing firms, NBER WP 10020. 
Figure 1: Industry exporting intensity

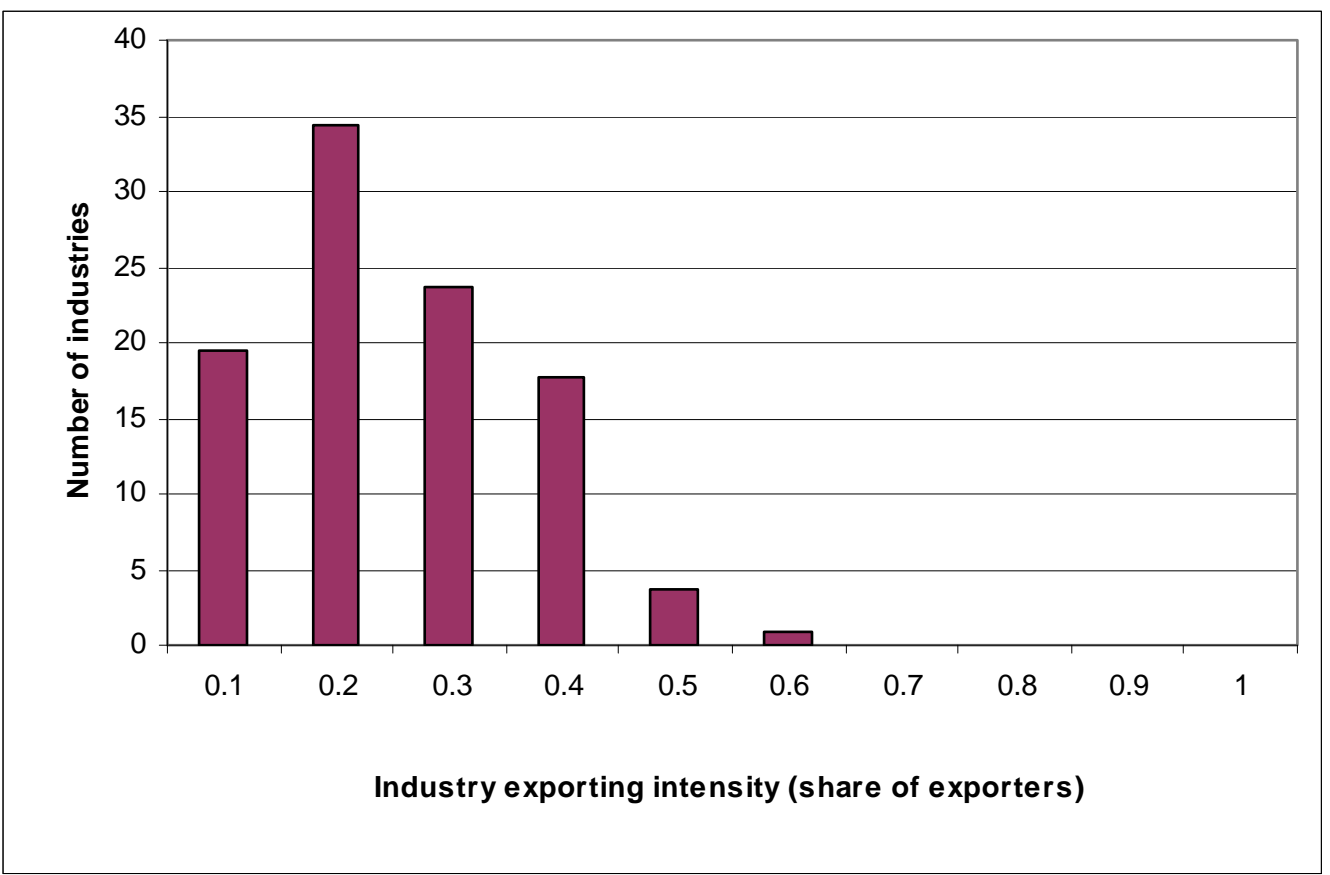


Figure 2: Aggregate productivity and export intensity of the UK manufacturing

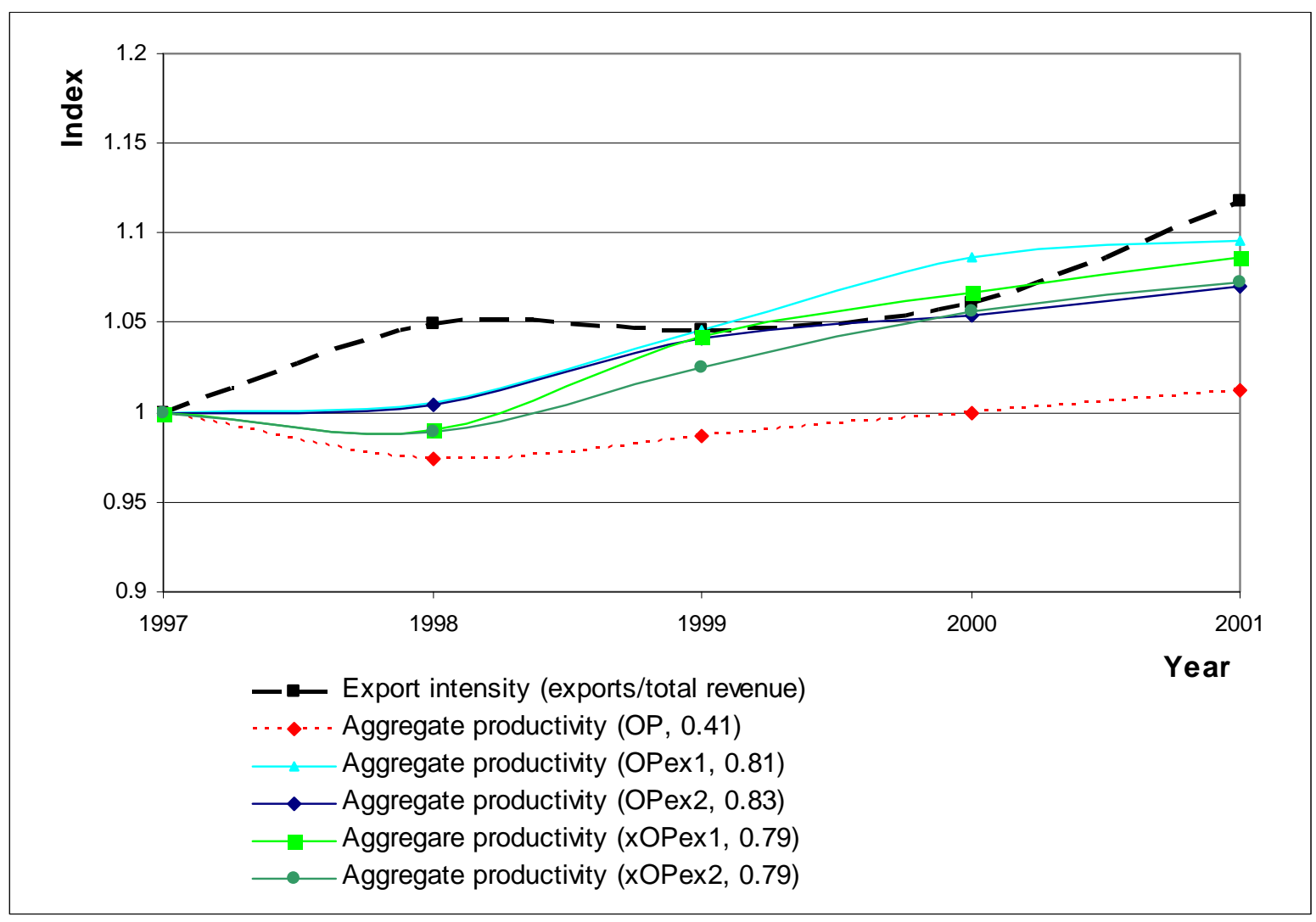

Note: Indexes are normalised at 1 for 1997; correlation coefficients between aggregate productivity, for each productivity measure, and export intensity are reported in the parentheses. 
Table 1: Company level facts on exporting

\begin{tabular}{lll}
\hline Exporter share & Percentage of all companies & Percentage of total output \\
\hline Productivity & 15.6 & 74.4 \\
\hline $\begin{array}{l}\text { Labour productivity (LP), within total } \\
\text { manufacturing }\end{array}$ & Standard deviation of log productivity (\%) & $\begin{array}{l}\text { Exporter less non-exporter average log } \\
\text { productivity (\%) }\end{array}$ \\
$\begin{array}{l}\text { Labour productivity (LP), within 4-digit } \\
\text { industries }\end{array}$ & 90.2 & 16.8 \\
\hline Exporter size advantage & 85.2 & 13.3 \\
\hline & Ratio of average UK sales & \\
\hline Export intensity (\%) & 3.8 & Ratio of average total sales \\
\hline 0 to 30 & Percentage of all exporters & 6.5 \\
\hline 0 to 70 & 66.7 & Percentage of total output of exporters \\
70 to 100 & 25.8 & 41.7 \\
\hline
\end{tabular}

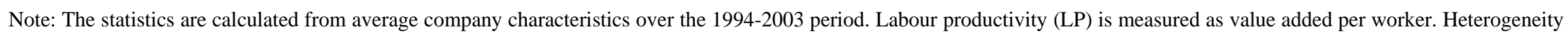

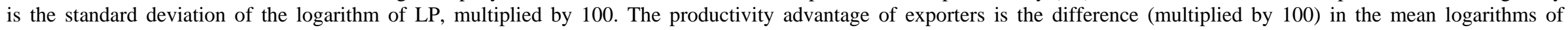

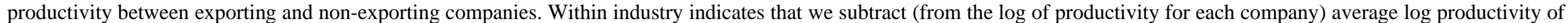

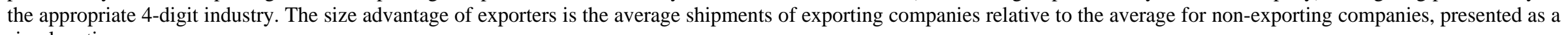
simple ratio. 
Table 2: Summary statistics

\begin{tabular}{|c|c|c|c|c|c|c|c|c|c|c|c|c|c|c|c|}
\hline \multirow[t]{2}{*}{ Variables } & \multicolumn{3}{|c|}{ Age } & \multicolumn{3}{|c|}{ Value added } & \multicolumn{3}{|c|}{ Total fixed assets } & \multicolumn{3}{|c|}{ Employment } & \multicolumn{3}{|c|}{ Investment } \\
\hline & $\mathbf{E}$ & $\mathbf{N}$ & $\mathbf{T}$ & $\mathbf{E}$ & $\mathbf{N}$ & $\mathbf{T}$ & $\mathbf{E}$ & $\mathbf{N}$ & $\mathbf{T}$ & $\mathbf{E}$ & $\mathbf{N}$ & $\mathbf{T}$ & $\mathbf{E}$ & $\mathbf{N}$ & $\mathbf{T}$ \\
\hline \multirow[t]{2}{*}{1997} & 28.9 & 25.3 & 27.4 & 24.8 & 8.5 & 18.1 & 25.6 & 9.0 & 18.7 & 626 & 266 & 477 & 5.4 & 2.4 & 4.2 \\
\hline & $(24.0)$ & (21.6) & (23.1) & $(272.8)$ & $(46.3)$ & $(211.0)$ & (403.6) & (54.1) & (310.8) & (3197) & (1263) & (2584) & $(75.2)$ & $(17.6)$ & $(58.7)$ \\
\hline \multirow[t]{2}{*}{1998} & 28.5 & 25.0 & 27.0 & 24.0 & 8.7 & 17.4 & 28.9 & 8.0 & 19.9 & 596 & 263 & 453 & 11.6 & 2.2 & 7.5 \\
\hline & (23.7) & (21.4) & (22.8) & $(277.5)$ & $(48.8)$ & $(212.0)$ & $(629.7)$ & $(46.6)$ & $(476.4)$ & (3823) & (1177) & (2991) & (360.9) & $(14.0)$ & (272.6) \\
\hline \multirow[t]{2}{*}{1999} & 28.4 & 24.5 & 26.7 & 25.6 & 8.9 & 18.3 & 27.3 & 7.8 & 18.8 & 557 & 258 & 427 & 5.7 & 2.2 & 4.2 \\
\hline & (23.6) & (20.9) & (22.5) & (319.7) & $(50.0)$ & (242.4) & (616.5) & (36.2) & (463.5) & (3615) & (1066) & (2807) & (98.4) & (18.9) & (74.9) \\
\hline \multirow[t]{2}{*}{2000} & 28.6 & 24.9 & 27.0 & 25.2 & 10.7 & 18.9 & 33.8 & 8.5 & 22.8 & 518 & 272 & 411 & 10.7 & 2.2 & 7.0 \\
\hline & (23.5) & (21.1) & (22.6) & (355.6) & (59.9) & $(270.2)$ & $(948.0)$ & $(44.6)$ & (713.2) & (3214) & (1114) & (2528) & (411.8) & (30.2) & (310.1) \\
\hline \multirow[t]{2}{*}{2001} & 28.7 & 24.8 & 27.0 & 27.4 & 11.2 & 20.2 & 36.5 & 9.4 & 24.6 & 528 & 286 & 422 & 6.0 & 2.0 & 4.3 \\
\hline & (23.6) & $(21.4)$ & (22.7) & (416.1) & $(63.6)$ & (314.2) & (1013.5) & $(55.6)$ & (759.2) & (3262) & (1318) & (2595) & (145.3) & $(23.0)$ & (109.8) \\
\hline \multirow[t]{2}{*}{ Average } & 28.6 & 24.9 & 27.0 & 25.4 & 9.6 & 18.6 & 30.4 & 8.5 & 21.0 & 564 & 269 & 437 & 7.9 & 2.2 & 5.5 \\
\hline & (23.7) & (21.2) & (22.7) & (332.9) & (54.4) & (253.6) & $(760.0)$ & $(47.6)$ & (573.7) & (3437) & (1187) & (2710) & (262.4) & $(21.6)$ & (198.3) \\
\hline
\end{tabular}

Note: Total number of observations, after applying lags and deleting observations with missing values, for the smallest estimated sample covering five years and the 1997-2001

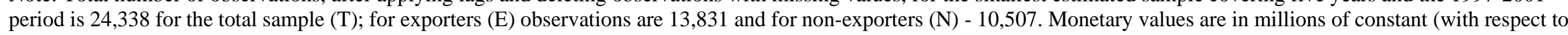
year 2000) pounds sterling. Standard deviations are in parentheses. 
Table 3: Weighted average coefficient estimates for the total sample of UK manufacturing companies

\begin{tabular}{|c|c|c|c|c|c|c|c|c|c|c|c|}
\hline \multirow[t]{5}{*}{ Parameters } & \multicolumn{11}{|c|}{ Estimation method } \\
\hline & \multirow{2}{*}{\multicolumn{3}{|c|}{ Export status not considered }} & \multicolumn{8}{|c|}{ Export status considered } \\
\hline & & & & \multicolumn{2}{|c|}{ Exogenous } & \multicolumn{6}{|c|}{ Endogenous } \\
\hline & \multirow[t]{2}{*}{ OLS } & \multirow[t]{2}{*}{$\mathrm{GLS}_{\mathrm{fe}}$} & \multirow[t]{2}{*}{$\mathrm{OP}$} & \multirow{2}{*}{$\begin{array}{c}\text { OP } 1^{\text {st }} \\
\text { order MP }\end{array}$} & \multirow{2}{*}{$\begin{array}{r}\text { OP } 2^{\text {nd }} \\
\text { order MP } \\
\end{array}$} & \multirow{2}{*}{$\begin{array}{r}\text { OP } 1^{\text {st }} \\
\text { order MP }\end{array}$} & \multirow{2}{*}{$\begin{array}{r}\text { OP } 2^{\text {nd }} \\
\text { order MP }\end{array}$} & \multicolumn{2}{|c|}{$\mathrm{OP} 1^{\text {st }}$ order MP } & \multicolumn{2}{|c|}{ OP $2^{\text {nd }}$ order MP } \\
\hline & & & & & & & & $\mathrm{E}$ & $\mathrm{NE}$ & $\mathrm{E}$ & $\mathrm{NE}$ \\
\hline$(1)$ & $(2)$ & (3) & $(4)$ & $(5)$ & $(6)$ & $(7)$ & $(8)$ & (9) & $(10)$ & $(11)$ & $(12)$ \\
\hline b_l & 0.70 & 0.47 & 0.61 & 0.61 & 0.66 & 0.61 & 0.66 & 0.56 & 0.65 & 0.59 & 0.68 \\
\hline s.e & 0.05 & 0.10 & 0.08 & 0.09 & 0.06 & 0.08 & 0.05 & 0.12 & 0.11 & 0.07 & 0.08 \\
\hline b_k & 0.21 & 0.13 & 0.29 & 0.29 & 0.24 & 0.28 & 0.26 & 0.28 & 0.26 & 0.28 & 0.26 \\
\hline s.e. & 0.04 & 0.06 & 0.05 & 0.05 & 0.04 & 0.05 & 0.04 & 0.07 & 0.06 & 0.05 & 0.05 \\
\hline b_a & 0.02 & -0.08 & -0.02 & -0.12 & 0.11 & 0.01 & 0.03 & 0.16 & 0.18 & -0.02 & 0.07 \\
\hline s.e & 0.06 & 0.42 & 0.11 & 0.15 & 0.10 & 0.11 & 0.07 & 0.16 & 0.13 & 0.08 & 0.09 \\
\hline $\log \omega$ & 3.24 & 4.94 & 3.14 & 3.24 & 3.19 & 3.29 & 3.32 & 3.57 & 3.18 & 3.59 & 3.06 \\
\hline s.d. & 0.75 & 1.06 & 0.81 & 0.82 & 0.79 & 0.82 & 0.79 & 1.08 & 1.08 & 0.98 & 0.98 \\
\hline $\log \omega^{*}$ & 3.26 & 5.02 & 3.16 & 3.25 & 3.18 & 3.31 & 3.29 & 3.55 & 3.09 & 3.57 & 3.04 \\
\hline s.d. & 0.11 & 0.31 & 0.53 & 0.57 & 0.54 & 0.59 & 0.57 & 0.90 & 0.90 & 0.83 & 0.83 \\
\hline $\mathrm{R}^{2}$ & 0.77 & 0.73 & 0.97 & 0.98 & 0.99 & 0.98 & 0.99 & 0.99 & 0.99 & 0.99 & 0.99 \\
\hline No obs. & 24,338 & 24,338 & 24,338 & 24,338 & 24,338 & 24,338 & 24,338 & 13,831 & 10,507 & 13,831 & 10,507 \\
\hline
\end{tabular}

Note: Coefficient estimates reported here are weighted averages of coefficients estimated within each 4-digit industry in the sample. $\omega$ is productivity measure with last stage estimation error and $\omega^{*}$ is productivity measure net of the last stage estimation error. Coefficients reported in bold are significant at the $1 \%$ level or better. 
Table 4 Decompositions of productivity change over the 1997-2001 period, by industry and export status

\begin{tabular}{|c|c|c|c|c|c|c|c|c|c|c|}
\hline \multirow{2}{*}{$\begin{array}{l}\text { Industry } \\
\text { (Obs.) }\end{array}$} & \multirow[t]{2}{*}{ Period } & \multirow{2}{*}{$\begin{array}{c}\text { Estimation } \\
\text { method }\end{array}$} & \multicolumn{4}{|c|}{ Exporters } & \multicolumn{4}{|c|}{ Non-exporters } \\
\hline & & & $\begin{array}{c}\text { Aggregate } \\
\text { productivity } \\
\text { in } 1997 \text { or } \\
2000(\log \omega)\end{array}$ & $\begin{array}{c}\text { Aggregate } \\
\text { productivity } \\
\text { change }\end{array}$ & $\begin{array}{c}\text { Within } \\
\text { company } \\
\text { productivity } \\
\text { change }\end{array}$ & $\begin{array}{c}\text { Share } \\
\text { reallocation } \\
\text { productivity } \\
\text { change }\end{array}$ & $\begin{array}{c}\text { Aggregate } \\
\text { productivity } \\
\text { in } 1997 \text { or } \\
2001(\log \omega)\end{array}$ & $\begin{array}{c}\text { Aggregate } \\
\text { productivity } \\
\text { change }\end{array}$ & $\begin{array}{c}\text { Within } \\
\text { company } \\
\text { productivity } \\
\text { change }\end{array}$ & $\begin{array}{c}\text { Share } \\
\text { reallocation } \\
\text { productivity } \\
\text { change }\end{array}$ \\
\hline (1) & $(2)$ & (3) & (4) & (5) & (6) & $(7)$ & (8) & (9) & $(10)$ & $(11)$ \\
\hline 15 & $97-98$ & xOPex2 & 4.30 & -5.8 & 0.4 & -6.2 & 3.01 & -3.6 & 1.6 & -5.2 \\
\hline Food and & & xOPex1 & 4.83 & -7.9 & 0.3 & -8.2 & 3.17 & -2.0 & 1.7 & -3.7 \\
\hline beverages & & OPex2 & 2.91 & -3.8 & 0.7 & -4.5 & 2.25 & -1.2 & 0.6 & -1.8 \\
\hline \multirow[t]{7}{*}{ (1394) } & & OPex1 & 2.88 & -2.8 & 0.4 & -3.2 & 2.18 & -1.3 & 0.7 & -2.0 \\
\hline & & OP & 3.33 & -1.0 & 2.2 & -3.2 & 2.96 & -4.2 & -0.8 & -3.4 \\
\hline & 00-01 & xOPex2 & 4.56 & 5.6 & 1.5 & 4.1 & 2.62 & 13.2 & 1.6 & 11.6 \\
\hline & & xOPex1 & 4.21 & 9.5 & 1.8 & 7.7 & 2.79 & 11.8 & 1.2 & 10.6 \\
\hline & & OPex2 & 2.46 & 5.1 & 0.8 & 4.3 & 2.17 & 7.6 & 2.6 & 5.0 \\
\hline & & OPex1 & 2.63 & 7.9 & 0.8 & 7.1 & 2.50 & 8.0 & 2.0 & 6.0 \\
\hline & & OP & 3.05 & 10.1 & 1.6 & 8.5 & 2.43 & 17.8 & 2.5 & 15.3 \\
\hline \multirow{10}{*}{$\begin{array}{r}18 \\
\text { Wearing } \\
\text { apparel } \\
(534)\end{array}$} & $97-98$ & xOPex2 & 5.65 & -3.5 & -0.2 & -3.3 & 3.82 & -0.1 & 0.2 & -0.3 \\
\hline & & xOPex1 & 5.24 & -3.7 & -0.1 & -3.6 & 4.05 & -0.1 & 0.3 & -0.4 \\
\hline & & OPex2 & 3.95 & -6.8 & -0.6 & -6.2 & 3.29 & -0.4 & 0.4 & -0.8 \\
\hline & & OPex1 & 4.07 & -5.1 & -0.5 & -4.6 & 3.40 & -0.7 & 0.3 & -1.0 \\
\hline & & OP & 2.62 & -10.5 & -1.8 & -8.7 & 2.46 & 0.1 & 2.8 & -2.9 \\
\hline & $00-01$ & xOPex2 & 5.86 & 4.6 & 0.9 & 3.7 & 3.91 & 2.5 & 2.8 & -0.3 \\
\hline & & xOPex1 & 5.42 & 5.1 & 1.1 & 4.0 & 4.17 & 2.4 & 2.5 & -0.1 \\
\hline & & OPex2 & 3.99 & 7.4 & 2.3 & 5.1 & 3.49 & 3.9 & 3.6 & 0.3 \\
\hline & & OPex1 & 4.17 & 6.6 & 2.3 & 4.3 & 3.54 & 2.9 & 2.4 & 0.5 \\
\hline & & OP & 2.91 & 15.5 & 7.2 & 8.3 & 2.72 & 5.5 & 5.3 & 0.2 \\
\hline
\end{tabular}


Table 4 continued

\begin{tabular}{|c|c|c|c|c|c|c|c|c|c|c|}
\hline (1) & $(2)$ & (3) & (4) & (5) & (6) & (7) & (8) & (9) & (10) & $(11)$ \\
\hline 21 & $97-98$ & xOPex2 & 3.86 & 7.1 & -4.4 & 11.5 & 2.81 & -9.4 & -6.9 & -2.5 \\
\hline Pulp and & & xOPex1 & 3.22 & 11.7 & -4.2 & 15.9 & 2.43 & -12.4 & -6.9 & -5.5 \\
\hline paper & & OPex2 & 3.48 & 5.7 & -1.5 & 7.2 & 3.33 & -5.6 & -4.5 & -1.1 \\
\hline \multirow[t]{7}{*}{ (894) } & & OPex1 & 3.70 & 6.0 & -1.8 & 7.8 & 3.60 & -6.5 & -4.3 & -2.2 \\
\hline & & $\mathrm{OP}$ & 3.56 & 2.2 & -2.8 & 5.0 & 3.41 & -5.0 & -4.2 & -0.8 \\
\hline & $00-01$ & xOPex2 & 3.68 & 4.7 & 2.0 & 2.7 & 2.21 & -2.9 & -1.1 & -1.8 \\
\hline & & xOPex1 & 3.24 & 4.6 & 2.7 & 1.9 & 2.45 & -3.4 & -1.4 & -2.0 \\
\hline & & OPex2 & 3.62 & 2.5 & 2.4 & 0.1 & 3.40 & -2.2 & -1.3 & -0.9 \\
\hline & & OPex1 & 4.07 & 2.3 & 2.2 & 0.1 & 3.67 & -3.3 & -1.2 & -2.1 \\
\hline & & $\mathrm{OP}$ & 3.77 & 2.4 & 1.7 & 0.7 & 3.46 & -2.1 & -0.9 & -1.2 \\
\hline & 97-98 & xOPex2 & 3.99 & 4.3 & -0.9 & 5.2 & 3.68 & -8.8 & 0.2 & -9.0 \\
\hline Publishing & & xOPex1 & 3.77 & 6.1 & -0.1 & 6.2 & 3.42 & -6.7 & 0.4 & -7.1 \\
\hline and & & OPex2 & 3.97 & 4.9 & -1.1 & 6.0 & 3.80 & -5.0 & 0.1 & -5.1 \\
\hline printing & & OPex1 & 4.26 & 7.9 & -0.6 & 8.5 & 4.23 & -7.2 & 0.6 & -7.8 \\
\hline \multirow[t]{6}{*}{ (4636) } & & $\mathrm{OP}$ & 4.69 & -1.6 & -0.6 & -1.0 & 4.24 & -10.6 & -1.0 & -9.6 \\
\hline & 00-01 & xОРex2 & 4.47 & 6.2 & 2.1 & 4.1 & 4.03 & -3.1 & -0.6 & -2.5 \\
\hline & & xOPex1 & 4.10 & 4.0 & 1.2 & 2.8 & 3.97 & -2.8 & -0.1 & -2.7 \\
\hline & & OPex2 & 4.27 & 5.4 & 0.9 & 4.5 & 3.77 & -2.1 & -0.4 & -1.7 \\
\hline & & OPex1 & 4.34 & 7.7 & 0.7 & 7.0 & 3.96 & -2.3 & -0.1 & -2.2 \\
\hline & & $\mathrm{OP}$ & 4.06 & -1.2 & 0.9 & -2.1 & 3.92 & -1.4 & -0.1 & -1.3 \\
\hline 23 to 26 & $97-98$ & xOPex2 & 3.71 & -9.4 & -1.0 & -8.4 & 3.41 & -12.0 & 1.3 & -13.3 \\
\hline Chemicals & & xOPex1 & 3.80 & -5.6 & -1.0 & -4.6 & 3.31 & -14.0 & 0.8 & -14.8 \\
\hline and fuel & & OPex2 & 4.20 & -5.4 & -1.3 & -4.1 & 4.02 & -7.1 & 0.7 & -7.8 \\
\hline \multirow[t]{7}{*}{ (4352) } & & Opex1 & 3.81 & -7.9 & -2.1 & -5.8 & 3.75 & -6.0 & 1.0 & -7.0 \\
\hline & & $\mathrm{OP}$ & 4.55 & -4.7 & -0.1 & -4.6 & 4.16 & -18.0 & 1.3 & -19.3 \\
\hline & $00-01$ & xOPex2 & 3.82 & 6.8 & 0.8 & 6.0 & 3.53 & -2.6 & -0.5 & -2.1 \\
\hline & & xOPex1 & 4.00 & 4.4 & 0.4 & 4.0 & 3.66 & -1.5 & -0.3 & -1.2 \\
\hline & & OPex2 & 4.29 & 3.0 & 0.1 & 2.9 & 4.17 & -2.6 & -0.7 & -1.9 \\
\hline & & Opex1 & 4.22 & 3.9 & 0.1 & 3.8 & 3.93 & -2.9 & -0.9 & -2.0 \\
\hline & & $\mathrm{OP}$ & 4.58 & 2.4 & 0.0 & 2.4 & 3.60 & 1.6 & 1.1 & 0.5 \\
\hline
\end{tabular}


Table 4 continued

\begin{tabular}{|c|c|c|c|c|c|c|c|c|c|c|}
\hline$(1)$ & (2) & (3) & (4) & (5) & (6) & (7) & (8) & (9) & (10) & (11) \\
\hline 27 and 28 & $97-98$ & xOPex2 & 3.20 & -2.6 & -2.3 & -0.3 & 2.74 & -1.9 & -2.3 & 0.4 \\
\hline Basic and & & xOPex1 & 3.55 & -3.4 & -2.6 & -0.8 & 3.19 & -2.0 & -2.8 & 0.8 \\
\hline fabricated & & Opex2 & 3.43 & -4.0 & -3.6 & -0.4 & 3.34 & -1.5 & -2.2 & 0.7 \\
\hline metals & & Opex1 & 3.68 & -4.2 & -3.4 & -0.8 & 3.55 & -1.7 & $-2,1$ & 0.4 \\
\hline \multirow[t]{6}{*}{ (2985) } & & OP & 1.67 & -4.1 & -6.6 & 2.5 & 1.62 & -1.6 & -1.8 & 0.2 \\
\hline & $00-01$ & xOPex2 & 3.30 & 5.8 & 1.1 & 4.7 & 2.62 & 1.3 & -1.3 & 2.6 \\
\hline & & xOPex1 & 3.62 & 4.9 & 1.2 & 3.7 & 3.00 & 2.4 & -1.5 & 3.9 \\
\hline & & Opex2 & 3.30 & 8.0 & 0.8 & 7.2 & 3.21 & 1.1 & -0.9 & 2.0 \\
\hline & & Opex1 & 3.52 & 9.3 & 0.6 & 8.7 & 3.39 & 1.4 & -0.8 & 2.2 \\
\hline & & OP & 1.71 & -5.4 & 3.3 & -8.7 & 1.57 & 1.0 & -1.9 & 2.9 \\
\hline 29 & $97-98$ & xOPex2 & 3,81 & 4.4 & -0.3 & 4.7 & 2.77 & 5.2 & 0.6 & 4.6 \\
\hline \multirow{9}{*}{$\begin{array}{r}\text { Non- } \\
\text { electrical } \\
\text { machinery } \\
\text { (1036) }\end{array}$} & & xOPex1 & 3.68 & 2.0 & -0.5 & 2.5 & 3.27 & 4.5 & 0.8 & 3.7 \\
\hline & & Opex2 & 3.13 & 4.0 & -1.2 & 5.2 & 3.01 & 5.2 & 0.3 & 4.8 \\
\hline & & Opex1 & 3.67 & 3.5 & -0.1 & 3.6 & 3.51 & 4.7 & 0.4 & 4.3 \\
\hline & & OP & 2.42 & 9.8 & 1.3 & 8.5 & 1.65 & 9.6 & 1.5 & 8.1 \\
\hline & 00-01 & xOPex2 & 3,68 & 13.8 & 4.6 & 9.2 & 2.83 & -4.5 & 2.3 & -6.8 \\
\hline & & xOPex1 & 3.58 & 7.3 & 3.3 & 4.0 & 3.37 & -3.2 & 1.8 & -5.0 \\
\hline & & Opex2 & 2.98 & 14.4 & 4.1 & 10.3 & 2.79 & -2.9 & 0.6 & -3.5 \\
\hline & & Opex1 & 3.59 & 9.0 & 3.4 & 5.6 & 3.52 & -3.5 & 1.7 & -5.2 \\
\hline & & OP & 2.49 & 12.6 & 4.6 & 8.0 & 1.68 & -13.6 & 3.7 & -17.3 \\
\hline 30 to 32 & & xOPex2 & 3.86 & 8.8 & 2.2 & 6.6 & 3.21 & -10.7 & 2.3 & -13.0 \\
\hline Electrical & & xOPex1 & 3.40 & 3.8 & 0.9 & 2.9 & 2.95 & -10.1 & 2.8 & -12.9 \\
\hline machinery & & Opex2 & 3.67 & 10.3 & 1.7 & 8.6 & 2.80 & -8.9 & 2.7 & -11.6 \\
\hline \multirow[t]{7}{*}{ (3054) } & & Opex1 & 3.25 & 8.2 & 1.0 & 7.2 & 3.07 & -8.8 & 2.6 & -11.4 \\
\hline & & $\mathrm{OP}$ & 3.11 & 7.6 & -0.2 & 7.8 & 2.97 & -8.1 & 4.5 & -12.6 \\
\hline & & xOPex2 & 3.66 & -2.4 & 4.5 & -6.9 & 3.08 & 7.5 & 1.9 & 5.6 \\
\hline & & xOPex1 & 3.76 & -3.4 & 4.9 & -8.3 & 3.22 & 6.2 & 0.4 & 5.8 \\
\hline & & Opex2 & 3.07 & -4.7 & 5.9 & -10.6 & 2.88 & 8.4 & 1.9 & 6.5 \\
\hline & & Opex1 & 3.56 & -6.0 & 4.8 & -10.8 & 3.33 & 9.7 & 1.8 & 7.9 \\
\hline & & OP & 3.09 & -9.2 & 4.7 & -13.9 & 2.79 & 13.9 & 1.9 & 12.0 \\
\hline
\end{tabular}


Table 4 continued

\begin{tabular}{|c|c|c|c|c|c|c|c|c|c|c|}
\hline (1) & (2) & (3) & (4) & (5) & (6) & (7) & (8) & (9) & $(10)$ & (11) \\
\hline 33 & & xOPex2 & 3.95 & -1.4 & 0.2 & -1.6 & 3.69 & -1.6 & 0.6 & -2.2 \\
\hline Precision & & xOPex1 & 4.56 & -1.4 & 0.4 & -1.8 & 3.87 & -1.7 & 0.7 & -2.4 \\
\hline instruments & & Opex2 & 3.97 & -1.7 & 0.4 & -2.1 & 3.20 & -1.9 & 0.0 & -1.9 \\
\hline \multirow[t]{7}{*}{ (1155) } & & Opex1 & 3.88 & -1.5 & 0.3 & -1.8 & 3.70 & -1.4 & 0.7 & -2.1 \\
\hline & & $\mathrm{OP}$ & 2.87 & -1.9 & 0.3 & -2.2 & 2.70 & -2.1 & 0.0 & -2.1 \\
\hline & & xOPex2 & 3.88 & 3.9 & 1.5 & 2.4 & 3.61 & 4.5 & 3.8 & 0.7 \\
\hline & & xOPex1 & 4.47 & 3.6 & 1.5 & 2.1 & 3.91 & 3.8 & 3.4 & 0.4 \\
\hline & & Opex2 & 3.93 & 4.8 & 2.0 & 2.8 & 3.51 & 4.7 & 3.6 & 1.1 \\
\hline & & Opex1 & 3.81 & 4.0 & 1.6 & 2.4 & 3.52 & 4.4 & 3.5 & 0.9 \\
\hline & & $\mathrm{OP}$ & 2.83 & 5.0 & 2.2 & 2.8 & 2.67 & 4.8 & 4.0 & 0.8 \\
\hline 34 and 35 & & xOPex2 & 4.00 & 3.7 & -2.8 & 6.5 & 2.16 & 4.6 & 5.6 & -1.0 \\
\hline Transportation & & xOPex1 & 3.88 & 4.3 & -3.3 & 7.6 & 2.61 & 2.7 & 4.6 & -1.9 \\
\hline equipment & & OPex2 & 4.01 & 5.4 & -2.9 & 8.3 & 2.59 & 3.7 & 3.8 & -0.1 \\
\hline \multirow[t]{7}{*}{ (976) } & & OPex1 & 3.99 & 9.4 & -2.1 & 11.5 & 3.31 & 5.8 & 4.0 & 1.8 \\
\hline & & $\mathrm{OP}$ & 3.02 & 13.6 & -3.0 & 16.6 & 2.47 & 6.8 & 3.3 & 3.5 \\
\hline & & xOPex2 & 4.26 & 4.6 & 2.0 & 2.6 & 2.91 & -1.4 & 7.9 & -9.3 \\
\hline & & xOPex1 & 4.24 & 4.8 & 2.3 & 2.5 & 3.78 & -1.4 & 6.0 & -7.6 \\
\hline & & OPex2 & 4.19 & 2.0 & 0.6 & 1.4 & 3.33 & -1.2 & 6.5 & -7.8 \\
\hline & & OPex1 & 4.17 & 4.3 & 1.0 & 3.3 & 3.66 & -0.9 & 4.8 & -5.7 \\
\hline & & $\mathrm{OP}$ & 3.24 & 4.9 & 0.8 & 4.1 & 2.96 & 2.3 & 6.5 & -4.2 \\
\hline \multirow{10}{*}{$\begin{array}{r}36 \\
\text { Furniture and } \\
\text { other } \\
\text { manufacturing } \\
\text { (2737) }\end{array}$} & $97-98$ & xOPex2 & 3.24 & -1.5 & -0.5 & -1.0 & 2.75 & 0.6 & -1.0 & 1.6 \\
\hline & & xOPex1 & 2.64 & -1.8 & -0.1 & -1.7 & 2.44 & 1.2 & -0.9 & 2.1 \\
\hline & & OPex2 & 2.79 & -1.3 & -0.3 & -1.0 & 2.67 & 1.4 & -0.7 & 2.1 \\
\hline & & OPex1 & 2.82 & -1.5 & -0.4 & -1.1 & 2.36 & 1.3 & -1.3 & 2.6 \\
\hline & & $\mathrm{OP}$ & 2.76 & -1.2 & -0.8 & -0.4 & 2.45 & 0.6 & -1.6 & 2.2 \\
\hline & 00-01 & xOPex2 & 3.33 & 2.9 & 0.4 & 2.5 & 2.85 & 6.9 & 3.7 & 3.2 \\
\hline & & xOPex1 & 2.73 & 5.5 & 1.1 & 4.4 & 2.56 & 6.0 & 3.0 & 3.3 \\
\hline & & OPex2 & 2.68 & 4.0 & 0.7 & 3.3 & 2.56 & 6.4 & 4.9 & 1.5 \\
\hline & & OPex1 & 2.60 & 3.9 & 0.8 & 3.1 & 2.55 & 9.3 & 5.4 & 3.9 \\
\hline & & $\mathrm{OP}$ & 2.84 & 0.6 & -0.4 & 1.0 & 2.66 & 5.8 & 3.9 & 1.9 \\
\hline
\end{tabular}




\section{Table 4 continued}

\begin{tabular}{|c|c|c|c|c|c|c|c|c|c|c|}
\hline$(1)$ & $(2)$ & (3) & (4) & (5) & (6) & (7) & (8) & (9) & $(10)$ & $(11)$ \\
\hline Total & $97-98$ & xOPex2 & 3.83 & 2.6 & -0.6 & 3.2 & 3.14 & -7.4 & -0.3 & -7.1 \\
\hline manufacturing & & xOPex1 & 3.88 & 2.6 & -0.3 & 2.9 & 3.51 & -6.0 & -0.4 & -5.6 \\
\hline \multirow[t]{8}{*}{ (24338) } & & OPex2 & 3.58 & 4.9 & -0.6 & 5.5 & 3.30 & -3.7 & -0.1 & -3.6 \\
\hline & & OPex1 & 3.62 & 5.0 & -0.3 & 5.3 & 3.40 & -3.4 & -0.1 & -3.3 \\
\hline & & $\mathrm{OP}$ & 3.87 & -1.2 & -0.5 & -0.7 & 3.28 & -9.2 & -0.2 & -9.0 \\
\hline & 00-01 & xOPex2 & 3.66 & 5.0 & 1.8 & 3.2 & 3.28 & 1.0 & 3.9 & -4.9 \\
\hline & & xOPex1 & 3.81 & 6.0 & 1.5 & 4.5 & 3.37 & 1.3 & 2.6 & -1.3 \\
\hline & & OPex2 & 3.76 & 3.5 & 1.3 & 2.2 & 3.45 & 1.0 & 3.5 & -2.5 \\
\hline & & OPex1 & 3.98 & 3.7 & 1.3 & 2.4 & 3.56 & 0.4 & 3.1 & -2.7 \\
\hline & & $\mathrm{OP}$ & 3.89 & 1.1 & 1.6 & -0.5 & 3.20 & 3.2 & 1.0 & 2.2 \\
\hline
\end{tabular}

Note: xOPex2 denotes a productivity measure of productivity calculated separately for exporter and non-exporter sub-samples and modelling omega as $2^{\text {nd }}$ order endogenous (instrumenting export variable with predicted value) Markov process. Analogously, xOPex1 is a productivity measure where $1^{\text {st }}$ order endogenous Markov process is modelled; OPex2 is a measure where $2^{\text {nd }}$ order endogenous Markov process is modelled and the estimation is done for the pooled sample of exporters and non-exporters; OPex1 is a measure

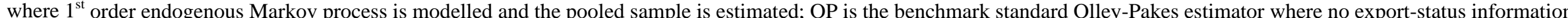
is used. Results reported for total manufacturing are not weighted by industry. 